\title{
Viharfelhők a Róma villa felett A Rippl-Rónai hagyaték utóélete
}

\author{
GÁSPÁR FERENC
}

7400 Kaposvár, Kossuth Lajos utca 10., e-mail: drgasparferenc@t-online.hu

\begin{abstract}
GÁSPÁR, F.: Storm clouds above the "Róma Villa". The afterlife of the Rippl-Rónai legacy.

Abstract: János Milán Horváth has already published a study on the 'legacy of Rippl-Rónai already existing by the time of his death' in the 1992 issue of the Publications of the Museums of Somogy County. We continue this story. In this work of ours we follow the afterlife of this legacy and finish the review with the years after the death of Baudrion Lazarine, the general heir of the legator. The research has showed us such correlations and events that extended the circle of inspection and enrich our knowledge with brand new data on the faith of the artistic oeuvre of József Rippl-Rónai. We present the story of a painting that had gone missing from the "Róma Villa" after the painter's death and later came back to its owner. We also present the documents in connection with the initial era of the Völgyessy collection that became quite significant later on.
\end{abstract}

Keywords: Final will and testament, Baudrion Lazarine, Anella Páris, Ferenc Völgyessy, lawsuit

Rippl-Rónai József „halálának pillanatában megvolt hagyatékáról” a Somogyi Múzeumok Közleményei 1992. évi kötetében már olvashattunk részletező tanulmányt. ${ }^{1}$ Folytatva a történetet, jelen munkánkban a hagyaték utóéletét követjük, az örökhagyó általános örököse, Baudrion Lazarine elhunyta utáni évekkel zárva a feltárást. A kutatás számos olyan összefüggésre, történésre is ráirányította a figyelmünket, amelyek kibővítették a vizsgálódás körét és új ismeretekkel gazdagítják Rippl-Rónai József müvészi életmúvének sorsával kapcsolatos tudásunkat. Bemutatjuk egy, a festő halála után a Róma villából eltűnt festmény tulajdonosához való visszakerülésének folyamatát, és a későbbiekben jelentőssé váló Völgyessy gyűjtemény kezdeti időszakához kapcsolódó dokumentumokat.

$$
\text { *** }
$$

1947. július 7-én 82 éves korában meghalt a Róma villa lakója özvegy Rippl-Rónai Józsefné született Baudrion Lazarine. ${ }^{2}$ Három nappal később a Somogyi Világosság című lapban megjelent, hogy „a nagy halottat Kaposvár város saját halottjának tekinti és a feledhetetlen mủvész megboldogult özvegyével szembeni elismerés ellenértékeképpen gondoskodik a temetés megszervezéséről. [...] Elhunyt után a

1 Horváth, J. 1992: 143-168

2 Baudrion Lazarine (1865-1947) Rippl-Rónai 1888-ban ismerte meg Neuilly-ben. Hímzőnőként közreműködött a nagy sikereket hozó falikárpitok kivitelezésében. 1906 májusában házasodtak össze. Nyughelye férje mellett a kaposvári Keleti temetőben van. müvész unokaöccse dr. Rónai Gusztáv törvényszéki tanácselnök és dr. Martyn Róbert egyetemi magántanár maradt vissza, mint gyászoló rokonok" ${ }^{3}$ - és örökösök; tehetjük hozzá mi.

Lazarine végrendelete tömör és egyértelmű volt. „Ép elmével, minden fizikai és lelki kényszer nélkül mindent megfontolva az alábbiak szerint végrendelkezem: Kaposváron fekvő és telekkönyvi tulajdonomat képező összes ingatlanaimat nevelt fiamra, dr. Martyn Róbert Kaposvári orvosra hagyom. [...]" 4

A sajtó híradásban említett másik „gyászoló rokon”, dr. Rónai Gusztáv a végrendeletben nincs nevesítve, mert őt - amint azt a későbbiekben bemutatjuk - RipplRónai József már korábban, 1927-ben, saját vagyonhányadának egyedüli örökösévé tette.

Baudrion Lazarine unokahúga, a Rippl-Rónai házaspár nevelt lánya Paris Anella, ${ }^{5}$ (akit a kijelölt egyedüli örökössel ellentétben tényleges vérségi kapcsolat is kötött az elhunythoz) joggal tarthatta magát várományosnak. Egy a későbbiekben részletesen ismertetendő bírósági tárgyalás során bizonyítékként terjesztett elő olyan levelet, amelyet nagynénje „röviddel halála előtt" utolsóként írt neki. Ebben nem lelünk utalást semmilyen olyan közöttük meglévő ellentétre, elhidegülésre vagy elvárásra, amelyet baljós előjelként érzékelhetett volna. Kételyei nem lehettek, mert még nagyon jól emlékezett egy korábbi, Rippl-Rónai József és közötte lezajlott beszélgetésre, amelyet az 1962ben leírt emlékezése nyomán idézhetünk:

3 Somogyi Világosság II. 1947, 153, 3

Feltűnő, hogy a helyi sajtóban mennyire nem volt hírértéke Baudrion Lazarine halálának. Az idézetten túlmenően mindössze két további nekrológról van tudomásunk, amelyek fővárosi lapokban jelentek meg: a Demokrácia, 1947, 30. 2 és a Színház, 1947, 32. 17 emlékezett meg róla.

4 Horváth, J. 1992: 144

dr. Martyn Róbert (1904 -1999) a „szegények orvosa”, a legendás „hegyi tanár” 1933-41 között a budapesti Gyermekklinikán dolgozik, 1941-től a kolozsvári Gyermekklinika adjunktusa, majd magántanára. A háborút követően hazatér, Kaposváron praktizál közben (1952-62 között) a Marcali kórház osztályvezető főorvosa. 1999-ben Kaposvár díszpolgára. Lazarine kezelőorvosa volt, a Róma villában élt.

5 Paris Anella (1899-1974). Édesanyja halálát követően 1910-ben hozta magával nagynénje, Lazarine Franciaországból. RipplRónaiék nevelt lányaként részese és átélője a mindennapok eseményeinek. 1962-ben írta meg visszaemlékezéseit, amelyben pontos krónikásként és nagy szeretettel beszél nevelőszüleiröl. 
„Lajos öccse, és családja nyáron, a szüret utánig kint szoktak lakni a Róma hegyen, a villához közel fekvő présházukban. Így Lajos bácsi majdnem minden délelőtt átjött Józsi bácsihoz, de mindig csak a müterem felé vette útját, ahol már rendszerint Józsi bácsi várta. Egyik este Józsi bácsi megemlítette, hogy másnap Lajos kihozza magával H. törvényszéki bírót és L. államvasúti főmérnököt és megírják együtt a végrendeletét.

Másnap - úgy, mint eddig is majdnem minden nap Józsi bácsi átsétált a műterembe, amint látta jönni a fasor végén a nevezett urakat Lajos bácsi társaságában. [...] Az egész tárgyalás nem tartott sokáig: Józsi bácsi nemsokára visszajött egyedül és amint a szobába belépett a végrendelettel a kezében, átnyújtotta férjemnek és azt mondta: Olvassa el Dobossy ${ }^{6}$, rendben van-e?

Férjem elolvasta az írást és visszaadta azzal, «Ha Józsi bátyám így akarta, akkor rendben van.»

Ebéd után Lazarine néni az ebédlőben maradt, hogy megfőzze a feketét, én pedig Józsi bácsit kikísértem a ház előtt lévő kőasztalhoz - ahol letelepedtünk. Ekkor Józsi bácsi azt a meglepő kérdést intézte hozzám: «Na, kisöreg, hogy vagy megelégedve a végrendeletemmel?»

Én ebéd előtt már megtudtam férjemtől, hogy Józsi bácsi egyedüli örökösének Lajos fiát [Gusztávot GF] jelölte ki; Györgyöt, - Sándor öccse fiát - és engem meg sem említett. Így azt feleltem: «Miért lennék megelégedve, hiszen Gyuri unokaöccsét, sem engem nem említ meg végrendeletében? »

Erre ő azt felelte: «Minek említselek meg Téged, hiszen Te - úgy mint Guszti az enyém - Lazarine néni örököse vagy.» ${ }^{7}$

6 Dobossy Elek (1890-1962) katonatiszt, később cégvezető. RipplRónai az ő édesapjától vásárolta meg a Róma villát. 1919 szeptemberében házasságot kötött Anellával, ezt követöen 1921-ben költöztek Budapestre. Már házasságkötése előtt vásárolgatott alkotásokat Rippl-től, később Szőnyi Istvántól is. 1915 szeptemberében Rippl-Rónai háborús festményeinek és rajzainak Ernst- Múzeumban rendezett kiállításán „egy chartreusi tájkép” és az Anella olvassa a háborús híreket (akvarell) című művek kerültek birtokába.

Jelentős müveket mondhattak magukénak (azonosíthatóságukra a Magyar Nemzeti Galéria Rippl-Rónai Gyűjteményes Kiállítása Budapest, 1998 Katalógus adatait adom meg) Claudine (Kat. 21), Katalán táj (Kat. 54), Place de l' Observatoire (Kat. 110), Ókulás néni (Kat. 124); valamint Pewny Denise: Rippl-Rónai József című kötetében a Legfontosabb múveinek lajstromába felvett Piros blúzos Anella.

A Rippl-Rónai József halálának 10 évfordulóján az Ernst Múzeumban megrendezett kiállíás katalógusának tanúsága szerint 1937ben tulajdonukban voltak még: Kat. 14. Merengő ifjú leány, színes ceruzarajz; Kat. 170. Darvas Lili az „Égi és földi szerelemben”, színezett nyomat; Kat. 173. Illusztráció Rodenbach „Les Vierges” címú művéhez, egyetlen példány; Kat. 177. Kertben, színes kőrajz.

Árverésen bukkant fel a Somogyi táj 20x39, olaj karon (Belvedere Szalon, 25. művészeti aukció 2009, Kat. 146), amelyet a hátoldalán található felirat szerint prof. dr. Rusznyák István vásárolt meg Dobossyéktól. A házaspár a későbbiekben meglehetősen szerény körülmények között élt, ezért folyamatos eladásokra kényszerültek: „megemlékezem még Genthon István (1903-1969) barátunk jóindulatú segítőkészségéről is, amellyel képeladásaink vonalán ismételten javított megszorult helyzetünkön"- írja Anella, visszaemlékezéseiben.

7 Horváth, J. 1995: 87- 88

A visszaemlékezésben szereplő személyek: dr. Rónai Gusztáv, a festő öccsének, Lajosnak volt egyetlen gyermeke. A legfiatalabb testvérrel Sándorral már korábban megszakadt a családi kapcsolat, mert eltiltás ellenére ugyancsak „Rónai” szignóval adta el saját festményeit. Az ellenérzés rávetült az ő fiára Györgyre (Gyuri) is.
A váratlan helyzet miatti csalódottságában és felháborodásában Anella érvényteleníteni akarta a végrendeletet - amely számára felért egy ostorcsapással -, hangsúlyozva, hogy az befolyásolás hatása alatt született meg.

Nem járt sikerrel, mert az okirat - annak ellenére, hogy nem saját kezüleg, hanem diktálás nyomán született - alakilag megfelelt az előírásoknak, így annak semmisségét kimondatni nem lehetett. ${ }^{8}$

Paris Anella és dr. Martyn Róbert, a két korán árvaságra jutott nevelt gyermek egyetértésben (és kijelenthetjük) szeretetben nevelkedett a Róma villában. Már korábban megegyeztek abban, hogy a majdan reájuk jutó örökséget kölcsönösen, azonos arányban megosztják egymás között. Most eljött az ideje az ígérvény teljesülésének. ${ }^{9}$

Anella nem a Róbertnek juttatott vagyonhányad fele-részét kérte nevére átíratni, hanem annak készpénzben történő megváltását. Abban az időben - 1947/48 fordulóján - már elterjedt vélekedés volt, hogy a földek, lakóingatlanok esetében az állam új „szabályozásokat" fog bevezetni, ezért, bár Martyn szóban megerősíti a korábbi megegyezés érvényességét, kijelenti, hogy a bizonytalan helyzet miatt fizetni csak akkor fog, ha bizonyossá válik, hogy nem államosítják azt. Ezzel együtt - az indoklás „kényes” jellege miatt - ezt a nyilatkozatot írásba adni nem hajlandó. ${ }^{10}$ Anella bizalmatlanná válik és ügyvédi segítséggel akarja felgyorsítani az események menetét.

Időközben az ügyben illetékes járásbíróság az örökösöknek kiadja a hagyatékot azzal, hogy Anella a Martynnak jutott rész felére támasztott igényét peres útra terelheti.

A felek perre nem mennek, az ingatlanok ügye lezárul, ${ }^{11}$ emellett azonban megnyílik az ingóságokkal kapcsolatos - számunkra az előbbinél lényegesebb és érdekesebb - újabb fejezet.

Anella számára természetes volt az ugyancsak nevelt gyermekeknek tekintett (nevezett) Martyn Ferenc és Róbert „kihagyása”, mert ök nem voltak vérszerinti rokonok. A fivérek édesanyjuk aki Rónai Lajos sógornője volt - korai halálát követően kerültek a Róma villába. Az idősebb fiú, Ferenc (a későbbi kiváló festőmüvész) esetében a kirekesztés érthető, mert ekkor Rippl-Rónai számára már „persona non grata”.

8 Tekintettel arra, hogy Lazarine-t életének utolsó éveiben egyedü dr. Martyn Róbert gondozta és gyógyította (Anelláék Pesten éltek), szándékolt befolyásolás nélkül is olyan érzelmi kötöttségbe kerülhetett vele, ami önállóan és önmagában elvezethetett a végrendelet ilyetén alakulásához. Mindezeken túlmenően Lazarine egész életében hajlamos volt a mások által eltúlzottnak minősíthető, szélsőséges magatartás formákra.

9 Páris Anella levele dr. Martyn Róberthez 1947. október 21. A szerző birtokában.

Jelentős vagyonról van szó: Rippl-Rónai „gazdaságának” földterülete összességében közel 15 holdat tett ki.

10 Martyn ebben az időben sehol nem kapott állást, „erdélyi menekültként" fenntartásokat érzékelt maga körül, ezért óvatosságból került minden olyan megnyilvánulást, amelyből - politikai színezetet adva neki - esetlegesen hátránya származhatott volna. Magánlevelezéséből van róla tudomásunk.

Aggálya nem volt alaptalan, a mezőgazdasági termelésre alkalmassá nyilvánított terület „termelőszövetkezeti” tulajdon lett, csak a villa körüli durván másfél hold maradt érintetlen.

11 6822/4 - 1948 számú járásbírósági határozat. Kelte: 1948. szeptember 5. Az ügyben keletkezett ügyvédi alkudozások iratanyagának ismertetése nem célom. 
Szokatlan módon, a hagyaték hivatalos leltározására, amelyen a hatóságok képviselői mellett a sajtóhíradásban megjelölt két rokon vett részt, csak jóval több, mint három hónap elteltével került sor. ${ }^{12}$

Nem célunk a teljes hagyatéki jegyzék bemutatása, a továbbiakban kizárólag a Hagyatéki leltár 5. csoport „Bútorok, szőnyegek, függönyök, tükrök, csillárok, képek, műtárgyak, könyvek, háztartási felszerelések, hasonlók" alatt feltüntetett tételekkel (mint az összes ide sorolandó elem teljes listájával) foglalkozunk. Ezek 1-10 sorszám alatt rögzítve a következők:

1.) $1 \mathrm{db}$. ebédlőasztal

2.) $4 \mathrm{db}$. szék

3.) $1 \mathrm{db}$. ruhaszekrény

4.) $1 \mathrm{db}$. ágy

5.) $1 \mathrm{db}$. dívány

6.) $1 \mathrm{db}$. tálalóasztal

7.) $1 \mathrm{db}$. konyhaasztal

8.) $1 \mathrm{db}$. stelázsi

9.) $1 \mathrm{db}$. kaszli

10.) Konyhaedények, stb (sic!)

Újabb traumát okozott Anella számára, hogy miután kézhez vette a hagyatéki okiratot, rádöbbent, hiányoznak azok a berendezési tárgyak a leltárból, amelyeket ő a temetést követően hat héttel még látott a Róma villában. Listája (festmények nélkül) 58 tételt nevesít. Önkényesen választva csak egyet emelek ki közülük: a sárga zongoraszoba lelkét, a házi koncertek kellékét, az Ehrbar zongorát. ${ }^{13}$

Mindezeken túlmenően kiemelten keres további olyan tárgyakat, amelyek már leány korában az ő személyes tulajdonát képezték, de Rippl-Rónai kérésére házasságkötését követően nem vitte azokat magával.

Ezek:

„1 empire asztal/gömbölyü, 3 lábú, rézveretes/, a hozzáillö 2 kis karosszék

1 eredeti Rippl-Rónai pasztell /fiú arcképe ${ }^{14} / . "$

Nem lehet szó nélkül elmenni a mellett a tény mellett, hogy bár a hagyatékban (és a leltárba felvéve) egyetlen Rippl-Rónai festmény sem szerepel, hiányuk

12 Hagyatéki kimutatás III. hitelesített példány, 1947. október 25. Száma: 211/1947.

A hagyatéki tárgyalásra Anellát is meghívták, de nem utazott le Budapeströl. Az eredeti dokumentumok, a leltár és az ügyvédek közötti levelezés a szerző birtokában vannak.

13 Valamennyi fellelhető végrendeletből hiányzik a rendelkezés az ingóságok vonatkozásában. Anella ennek alapján állítja azt, hogy azok meghatározott részét (az örökösödésröl rendelkező törvény alapján) jogosan követelheti magának. Levele 1947. december 4-én kelt, amire 10 nappal később dr. Rónai Gusztáv álláspontja is megérkezett. Kéri azoknak a tárgyak nevesítését, amelyekre Anella igényt tart, és „ha nem túlzott” a kívánság, teljesítik azt. Ez esetben - írja Rónai Gusztáv - az ingóságokra vonatkozó leltár „Szükségtelenné” válik. Úgy tünik, az ügy ezzel megoldódott, mert további egyezkedésre utaló iratok hiányoznak.

14 Pontosítását lehetővé tevő adatok nélkül. A bútort megkapta, a „kép” sorsáról nem tudok.

dr. Pesti Lipót ügyvéd (Anella jogi képviselője) levele a hagyatéki örökösök képviselőjéhez, dr. Mayer Ferenc kaposvári ügyvédhez 1947. december 3 nem tủnt fel a hatóságoknak. Hasonlóan csak feltevésekbe bocsátkoznánk, ha az örökségre jogosultak, vagy arra igényt formálók esetében a történtekkel kapcsolatosan valamely (bármely) lehetőség fennállását sugallnánk. Jogosnak tűnik a kutató dilemmája és bizonytalansága, annál is inkább, mert ezzel egyidejüleg egy pehelypaplan, vagy párnahuzat hiánya szóváltás tárgyává vált közöttük.

Az ingóságok vonatkozásában a hozzávetőlegesen tényleges hagyatékra következtethetünk abból a listából, amely a Róma villa és műterem dr. Martyn Róbert által 1970 októberében történt eladását követően (megvásárló: a magyar állam) az ingatlanban - kezdetben letétként - majd ajándékként ottmaradt berendezési tárgyak elemeit rögzíti. ${ }^{15}$ Lényegében napjainkban is ezeken nyugszik a Róma villa berendezésének hitelessége és egykori lakóinak „folyamatos jelenléte”. Hálával tartozunk dr. Martyn Róbertnek, hogy az utókor számára megőrizte a hagyaték elemeit és azok önzetlensége nyomán - ma már Kaposvár város tulajdonaként - a közjót szolgálják.

Egykoron, az ingatlanokon túlmenően, dr. Martyn Róbert tulajdonát képezte

$10 \mathrm{db}$. olaj/pasztell alkotás ${ }^{16}$

33 különféle technikájú grafikai mü

1 hímzett kárpit

$40 \mathrm{db}$. bútor, szőnyeg

$45 \mathrm{db}$. egyéb festmény, japán metszet, szobor, iparművészeti, berendezési és személyes tárgy, továbbá számos könyv, kiadványok, katalógusok, fényképek, levelek. ${ }^{17}$

A másik örökös, dr. Rónai Gusztáv tulajdonában - jelenlegi tudásunk szerint - 11 különféle technikával készült Rippl-Rónai mü volt. ${ }^{18}$

Az egész történet során rendre előkerül és általánosítóan nyomatékos érvként szerepel, hogy Lazarine és Anella kapcsolata már korábban oly mértékben megromlott, hogy az vezetett a hagyatékból való kizárásához. Szükséges tehát ennek ismertetésére is kitérnünk.

15 Horváth, J. 1992: 164-166

$16 \mathrm{Az} 1 . /$ lábjegyzet alatti tanulmányban nevesítetteken túlmenőn is tartalmazott a Martyn gyűjtemény kiemelkedő alkotásokat, mint pl. az Anella virágot tart (Lány virággal) 1912, és a Menetelő francia katonák 1914.

17 A tételes lista megismerhetö Horváth, J. 1992: 164-166

18 A Rónai Gusztáv tulajdonában lévő művek a Rippl-Rónai József halálának 10. évfordulójára rendezett Emlékkiállítás Ernst- Múzeum, 1937 november hó katalógusában feltüntetve: Kat. 11 Nagyon éhes, szopik (színes szénrajz), Kat. 37 Francia alakok (színes tusrajz) és Kat. 78 Szüleim szundikálnak (pasztell). Pewny Denise: Rippl-Rónai (1861-1927). Budapest, 1940 kötetében a Legfontosabb munkáinak lajstromában: Tábori mise, Batterie im forste, Virágcsendélet (valamennyi pasztell). A kaposvári Rippl-Rónai Emlékkiállítás Kaposvár, 1957 katalógusában: Apám 40 éves tanítói jubileumán, Stöger-Steiner és adjutánsa, Vezértörzsorvos, Apám, Anyám ebéd után, (feltehetően azonos az Ernst Múzeumban 1937-ben kiállított Szüleim szundikálnak címet viselő alkotással), Anyám és Lajos öcsém, Guszti öcsém. A katalógusban számozás és reprodukálás nélkül, de azonosításra alkalmas méret adatokkal. 
Rippl-Rónai József 1921- ben kelt végrendeletében olvashatjuk:

„Feleségem Baudrion Lazarine fogja élvezni - haláláig - az egész vagyonomat. Mindent. [...] Műveim elárverezése Budapesten lehetőleg Ernst Lajosnál menjen végbe [...] A befolyt összegek kamatait feleségem élvezze."19

1927. október 1-én, közeledni érezvén halálát, az előbbi végrendelet változatlanul hagyása mellett további kiegészítő - pontosító - rendelkezést tesz:

„Visszamaradt képeim ügyét kedves kis feleségem Lazarinkám Petrovics Elek barátomra, a Szépművészeti Múzeum főigazgatójára és Ernst Lajos barátomra bízom, hogy jól értékesíttessenek! Óhajtanám, hogy mindenben a segítségére legyenek. Okvetlen keresse fel őket! Kéri erre nagyon szerető Jóskája”.

A hátoldalon: „minden esetben Dobossy Elek, Anella férje bele legyen avatva a dologba. Rippl-Rónai”20

A festő halálát követően Lazarinon elhatalmasodott az elszegényedésétöl való félelem. Talán ennek is betudható, hogy az ésszerüségnek ellentmondóan egyszerre nagyszámú Rippl-Rónai művet áruba bocsátott.

Az Ernst Múzeumban 1928 decemberében rendezett emlékkiállításon, amely Rippl óhajának megfelelően Ernst Lajos és Dobossy Elek közreműködésével jött létre, 245 alkotás került a falakra, közülük a katalógusban 76 volt megvásárolhatóként feltüntetve. Feltehetően ebből a 76 képből (és még néhány a villában érzelmi okokból ottmaradt) alkotásból állhatott a hagyaték.

A következő „dömping” eladásra - amelyet ugyancsak az özvegy erőltetett - 1934. április 9-én került sor a budapesti Állami Árverési Csarnokban, ahol 53 mü került kalapács alá. A kiállított műveket ismerjük, az eladottakat nem. ${ }^{21}$ Az elökészületekben Dobossy Elek már nem vett részt. Érdemes megvizsgálnunk ennek okát.

A több, mint 300.000 példányszámban megjelenő Az Est, a magyar „szenzációsajtó” megtestesítője 1933. április 19-i, szombati száma közhírré teszi, hogy „Rippl-Rónai József eltünt öröksége nyomára vezette özvegyét". ${ }^{22}$ Lazarine meglehetősen mesés körülmények között megtalálja férje egy feljegyzését, miszerint 14.000 koronát helyezett el a Pesti Magyar Kereskedelmi Bankban számára, hogy majdani megélhetését abból biztosítsa. A betétet valaki már korábban, két részletben felvette: a személy azonosítására tett rendörségi nyomozás eredménytelen.

19 Horváth, J. 1992: 143

20 U.o.

21 Horváth, J. 1992: 166

A korabeli helyi sajtó sajnálkozott a művek alacsony ára miatt: „A gazdasági válság szomorú története, hogy ilyen csekély összegekért kerülnek dobra a század legnagyobb festőjének muzeális alkotásai.. Uj Somogy, 1934, 75. 3.

$\mathrm{Az}$ adott időszakban nem vallott nagy bölcsességre az a döntés, hogy a képeladásokból származó bevételt bankbetétben elhelyezve, a kamatokból lehet majd megélni. Lazarine későbbi életszínvonala ennek fényes bizonyítékát adta.

22 Az Est, 1933. 96. 5
Lazarine bűnvádi feljelentést tesz, amelynek fejleményéről a lap következő számában - az ügyre visszatérve - terjedelmes beszámolót közöl. Lényege, hogy „az elhunyt festőművész szelleme - éjjel, álmában rávezette Lazarine asszonyt a tettes kilétére". ${ }^{23}$

Ennek alapján a rendőrség beidézi és kihallgatja Dobossy Eleket. Valami egészen körmönfont, kétértelmü módon megfogalmazott, sejtetésekben bővelkedő tudósítói beszámolóból az olvasó képtelen eldönteni, hogy valójában tanúként, vagy már elkövetőként kezeli-e őt a nyomozó hatóság.

Dobossy elismeri, hogy mint egykoron Rippl-Rónai pénzügyeinek intézője valóban ő helyezte el a betétet a Kereskedelmi Bankban, de már korábban - a kedvezőbb kamatfeltételek miatt - az özvegy tudtával átvitte azt a Magyar Általános Takarékhoz és „közös egyetértésben a kaposvári kis gazdaság fenntartására és a háztartásra fordítottuk. Ezekről rendes (hiteles) feljegyzéseink vannak. Ezt a betétkönyvet egyébként évek óta az özvegy kezeli és él a pénzből. [...] Az egész „hagyaték" keresés csak egy nagyrészt ideges képzelet rémlátásai, vagy bosszú ${ }^{24}$ múve."

A lap a végkifejletről már nem számol be, így csak annyit mondhatunk: az ügy bűncselekmény elkövetésének hiányában lezárul.

A hírnevére igen kényes (ráadásul gyomorbajos) embert nagyon megviselte az igaztalan vád. Az esetet követően minden kapcsolatot megszakított az özvegygyel, még találkozni sem volt hajlandó vele.

Különösen bánthatta Dobossyt a méltatlanul elszenvedett meghurcolás, mert korábban, apósa állapotának rosszabbra fordulásával egy időben (1927), ő maga is otthagyva budapesti cégét, Kaposvárra költözött, és társult a már a Róma villában tartózkodó, az ápolásban tevékenyen közreműködő Anellához. RipplRónai halálát követően Lazarintól átvette a „birtok” irányítást és gazdálkodásból, főként sertések tenyésztéséből és eladásából próbált az özvegy számára megélhetést teremteni.
23 Az Est, 1933. 97.5 A fővárosi lap tudósítását átvette az Uj Somogy 1933. 96.3 és 97.1

24 Magántulajdonban lévő dokumentumok megismerése alapján kijelenthetjük, hogy a Dobossy házaspár és Lazarine között a mindennapok megélése során gyakoriak voltak a súrlódások, Lazarine nehezen viselte, és talán soha sem nyugodott bele, hogy nevelt lánya nem őt választva követte férjét Budapestre, ami miatt egyedül maradt a Róma villában. A másik két nevelt gyermeke hiányát elfogadhatónak tartotta: Róbert Kolozsváron élt, Ferenc Franciaországban. 
Közvetlenül a festő halálát követően, apósa iránti tiszteletből szeretett volna egy Rippl-Rónai művészi nagyságához méltó, reprezentatív, életrajzi kötetet megjelentetni, amelynek megírására Fülep Lajost tartotta a legalkalmasabb személynek. Nem rajta múlott, hogy a felkéréséből nem született eredmény. ${ }^{25}$

Anella, visszaemlékezve ezekre a nehéz napokra, soha nem mondott ítéletet nagynénje természetéről, de soraiból kiérződik keserüsége, hogy minden jó szándékuk ellenére el kellett elviselniük Lazarine örökös elégedetlenkedését, aki folyamatosan szemrehányásokkal halmozta el őket.

A Róma villában egyedül élő, befolyásolható természetű özvegyet egyre gyakrabban látogató alkalmi vevők és rámenős műkereskedők általában nem távoztak üres kézzel: több jelentős müalkotás vándorolt el ekkor Kaposvárról, amelyek további sorsát nem tudta, de nem is akarta követni. Lazarine olykor maga sem emlékezett rá, kinek mit adott (vagy ajándékozott) el.

Így történt ez egy jelentős korai alkotás esetében is, amelyhez pedig - vélhetnénk - komoly érzelmi kötődéssel kellett volna viszonyulnia, hiszen húgának arcképéről a Claudine (vagy Spanyol nő), címet viselő $42 \times 33 \mathrm{~cm}$-es olaj-vászon müről (1. ábra) beszélünk. ${ }^{26}$

Baudrion Lazarine-t, aki rövidesen Rippl-Rónai élettársa lett, és húgát Claudine -t a festő Neuillyben ismerte meg 1888-ban. Mindketten hímző nők voltak, közremüködtek Rippl kárpitjainak kivitelezésében. Négy évvel később 1892-ben készült róla az a remek portré, amelyen már megjelennek a „fekete korszak mély tónusai”. Több alkotáson is látható, olykor egymagában (Claudine hímez), máskor Lazarinnal kettesben, mint például a különféle változatokban ismert Hímző nők ${ }^{27}$-ön.

Anella hiába kérdezett rá a festmény hollétére, nagynénje nem tudott (akart?) neki felvilágosítást adni róla. A továbbiakban ennek a képnek sorsával foglalkozunk.

Rippl-Rónai József halálának huszadik évfordulóján, 1947 decemberében a Nemzeti Szalon emlékkiállítást rendezett tiszteletére. A katalógusban méret és a tulajdonos nevének feltüntetése nélkül összesen 131 alkotást láthattak az érdeklődők. ${ }^{28}$

25 F. Csanak, D. 1992: 357-397

Közli Dobossy Fülephez írt 14 levelét, amelyek 1927. december 23 és 1928. március 26 között keletkeztek. Dobossy szerette volna, ha Rippl-Rónairól szóló kötetet Fülep Lajos írja meg, ennek érdekében felajánlotta, hogy valamennyi a család rendelkezésére álló dokumentumot, Rippl levelezését, feljegyzéseit rendelkezésre bocsátja, mert: „életrajzot e nélkül is meg lehet írni, bizonyára többen meg is fogják írni - hallottam Pesten -, csak éppen ennek birtokában talán teljesebbet, kimerítőbbet." (609. számú levél). Az egyeztetés (Fülep részéről inkább alkudozásnak lehetne minősíteni) három hónapig elhúzódott, amelynek során Dobossy többszörösen megismételt kérése ellenére sem jött létre személyes találkozó közöttük. Időközben Lazarine is egyre újabb, fokozódó mértékủ jogdíj igénnyel lépett fel, aminek elfogadását nem lehetett elérni a kiadónál. Végül megunván a dolgot Dobossy szakított Füleppel.

26 MNG, 1998: 236

27 Himző nők. Olaj, vászon; 65x42. Rippl-Rónai Múzeum tulajdona. MNG. 1998: 253

28 Rippl-Rónai József Emlékkiállítás Nemzeti Szalon Művészeti Egyesület. Budapest, 1947. december 14-28

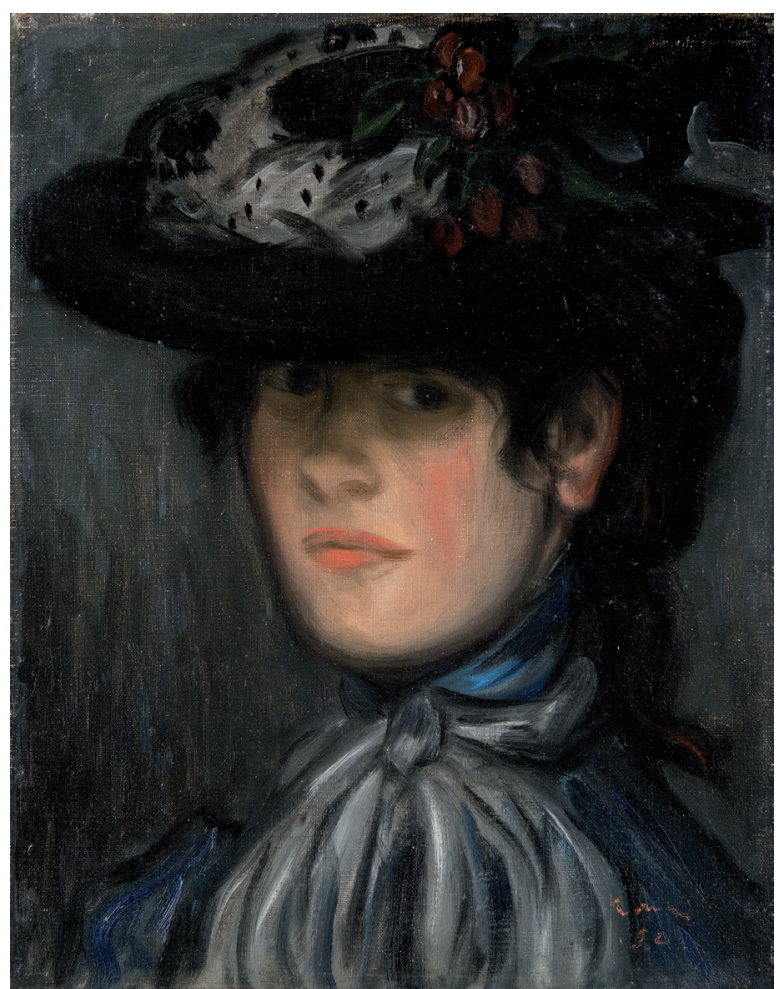

1. ábra. Rippl-Rónai József: Claudine Magyar Nemzeti Galéria tulajdona

Anella a nagyteremben, a fömüvek sorában felismeri az „elveszettnek” hitt Claudine portrét. Sikerül kiderítenie, hogy nem csak annak, hanem további fömüveknek is ugyanaz a tulajdonosa: dr. Völgyessy Ferenc (2. ábra) ${ }^{29}$. A kiállítás zárásához időzítve ügyvédi felszólítást küld, amelyben a Claudine portrét kéri vissza szolgáltatni.

Ebben olvashatjuk:

„Ügyfelem biztos tudomással bír arról, hogy a kérdéses képhez Főorvos Úr nem vásárlás útján jutott; ismeri azokat a körülményeket, amelyek következtében Főorvos Úr a fenti, valamint több más Rippl-Rónai kép és berendezési tárgyak tulajdonosa lett."

A kijelölt visszajuttatási határidő: 1948. január 10.

Völgyessy Ferenc elzárkózik ennek teljesítésétől, így per lett a dologból. A vallomásokat a tárgyaláson rögzített jegyzőkönyvek alapján ismertetjük

1.) „Pestvidéki törvényszék P.V. 1813/48/10 (1948. december 7)

Dobossy Elekné sz. Paris Anett, 50 éves, Issy-L. Eveque /Franciaország/ születésű lakos, férjes, felperes törvényes figyelmeztetés után:

29 A Völgyessy Ferenc tulajdonaként kiállított művek: A nagyteremben Kat. 12 Claudine, Kat. 22 Apám, Anyám 40 évi házasságuk után, Kat. 23 (Budapesti Történeti Múzeum tulajdona, MNG, 1998: 269.) Alkonyat egy intim szobában (Janus Pannonius Múzeum tulajdona, MNG, 1998: 242.) A jobb oldalteremben Kat. 67 vagy 76 Lazarine (két kép is azonos címet viselt) és Kat. 122 Fenella énekli Carment. 


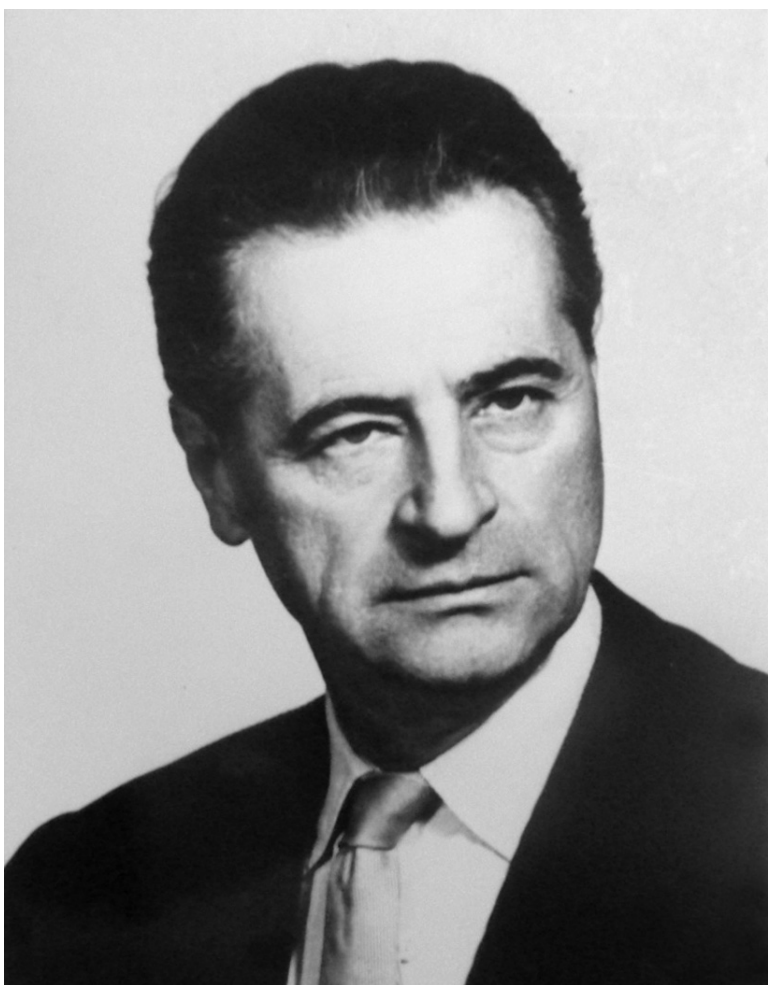

2. ábra. Völgyessy Ferenc arcképe. Magántulajdon.

A képet én 1918 karácsonyán kaptam a nevelő apámtól Rippl-Rónai Józseftől, Kaposváron, ahol én akkor éltem az ő háztartásukban, mint az ő nevelt lányuk. Vérségi kapcsolat is füzött hozzájuk, mert RipplRónai Józsefné az én édesanyámnak testvére, vagyis nekem nagynéném volt. Ez a kép a leánykori szobám falán lógott, a mosdó felett. Összesen két kép lógott ott abban a szobában a falon, úgy, hogy nem lehet róla tévedés, a másik kép az ágy mellett függött és az egy üvegre festett kis angyalfejet ábrázolt. A mosdó az ágy mellett volt, és a szoba az emeleten. Én 1919 évben mentem férjhez, és kezdetben még egy, vagy másfél évig Kaposváron éltünk. Azután elköltöztünk onnan 1921, vagy 1922 év őszén Budapestre. Budapestre költözésünkkor az a perbeli kép is, és a már említett angyalfejet ábrázoló másik kép is ott maradt Kaposváron, Rippl-Rónai Józseféknél. Nevelőapám Rippl-Rónai József 1927. november 25-én halt meg. Haláláig érintkezésben voltunk vele és halála után is az özveggyel. Özvegye maradt tovább ott ugyanabban a lakásban Kaposváron, de télen fel szokott járni hozzánk rendszeresen. A kép továbbra is ott maradt. Megemlítem, hogy 1927 októberében kiállítani akarta a mester a képet és akkor Budapesten volt az a kép. Akkor csináltattuk rája a jelenleg is rajta lévő brüsszeli rámát és pedig a férjem és én. De nem került kiállításra, mert elkésve ért be, és visszakerült a kép Kaposvárra. Úgy, hogy a mester halálakor a kép Kaposváron volt. A mester hagyatéká- ba nem lehetett bevéve ${ }^{30}$, mert az enyém volt. A mester özvegye, a nagynéném 1947 év nyaráig élt, július 7-én halt meg. Özvegysége ideje alatt is mindig Kaposváron élt. 1931 évben családi okok miatt megszakadt közöttünk az érintkezés. Tudniillik, akkor már hízelgőknek a befolyása alatt állott, körül volt véve hízelgőkel és ezért szakadt meg közöttünk az érintkezés. PI. az uramat feljelentette, beperelte, ezért volt közöttünk ellentét - illetve tulajdonképpen az ellentét nem a perlekedés miatt volt, ő csak bosszúból jelentett fel minket, mert megszakítottuk vele az érintkezést. A festőművész özvegye halálakor 82 éves volt. A perbeli kép 1931 ében évben is Kaposváron megvolt a régi helyén. 1940 vagy pedig 1941 évben a férjem hosszas könyörgésemre megengedte nekem, hogy haza mehessek Kaposvárra. Akkor a kép már nem volt ott. Kérdésemre nevelöanyám azt mondotta, hogy eladta, de hogy kinek, azt nem volt hajlandó elárulni. Így én ekkor már nem tudtam, hogy hol van a kép. A mester halálának huszadik évfordulóján, tehát 1947 év telén volt egy emlékkiállítás, itt, Budapesten a Nemzeti Szalonban. Ott én is megjelentem és rögtön megismertem az én képemet. Megkérdeztem a vezetőséget, azt hiszem Bernáth Aurélt, vagy Pátzay Pált, aki aztán megmondta, hogy az alperes küldte be kiállításra. Így tudtam meg, hogy a festmény az alperesnél van. Hogy mikor került az alpereshez, azt én nem tudom. Ekkor megkértem a perbeli ügyvédemet, hogy a kép visszaszerzése iránt tegyen lépéseket, és így indult meg ez a per. A kiállításon megtudtam azt is, hogy még egy képet másvalaki magáénak igényelt. Azt is alperes állította ki. Hogy a kép az enyém volt azt mindenki tudta, a nevelőanyám is tudta, és valószínü, hogy alperes is tudta. 1927 év őszén amikor a mester súlyos beteg volt, mi leköltöztünk Kaposvárra, de halála után nem tudtunk ott meglenni és ezért ismét felköltöztünk Budapestre, és akkor kértem a nevelőanyámat, hogy adja ide a képet, hogy elvigyem magammal Budapestre, de ő arra kért engem, hogy hagyjam ott nála addig, amíg ő él, mivel a Claudine, akit a kép ábrázol, az ő húga volt, az anyám.

Így maradt ott a kép.

Még 1942 év előtt értesültem arról, hogy írt a nevelőanyámnak egy orvos, hogy milyen nagy tisztelője a mesternek de nincs tőle képe, és kérte, hogy legalább egy kis rajzot küldjön neki. Tudtommal ez meg is történt, de hogy fizetett-e érte azt nem tudom. Én magam 1942-ben ismerkedtem meg az alperessel - de az évszámra nem emlékszem egészen biztosan - és pedig a nagynénémnél. Kaposváron aztán Rónay Gusztávtól megtudtam, hogy nevelőapám egyik főműve az alperesnek a szobájában van. Akkor alperes már Kaposváron élt. Apám, Anyám 40 évi házasságuk után ${ }^{31}$ a címe annak a festménynek. Dr. Rónainak, aki érdeklődött, hogy hogyan került a kép oda, alperes azt mondta,

30 Ez az állítás jelenlegi tudomásom szerint nem tartható: müalkotások leltárával (listáiával) nem találkoztam.

31 Időnként zavarokat okoz, hogy ugyanazon müalkotás egymástól eltérő elnevezéssel is szerepel a különböző kiállításokon, illetve katalógusokban. Jelen esetben: Apám, Anyám 40 évi házasságuk után, Szüleim negyvenévi házasság után és a Szüleim cím egyaránt elöfordul. A perben elhangzott tanú vallomásokban gyakorta csak Apám, Anyám címen kerül említésre. 
hogy kölcsönbe kapta, hogy díszítse a szoba falát, hogy ne legyen olyan komor. Erről a képről tudom, hogy a nevelőapámnak a legfőbb kívánsága volt, hogy a kaposvári múzeumba kerüljön halála után, ezért fáj nekem, hogy az alpereshez jutott. Az való, hogy az Apám, Anyám 40 éves házasság után című festményt az özvegy eladni akarta, 20 ezer pengőt akart érette kapni, de nem történt meg a vétel. Én panaszkodtam Petrovics Eleknek, hogy az özvegytől mindenét elviszik, és erre írta nekem az F/4 alatti levelet. ${ }^{32} \mathrm{Az} F / 3$ alatti levélnek a története az, hogy én írtam Martyn Róbertnek is, hogy csináljon valamit, és erre válaszolt nekem ezzel a levéllel. ${ }^{33}$

Alperes kérdésére: Karácsony volt és karácsonyfa alá volt helyezve ez a kép az én részemre, és egy cédula volt rátéve a mester kézírásával, hogy «a kisöregé karácsonyra», tudniillik a mester így szólított engem. Így történt ennek a képnek a részemre való ajándékozása."

Ezt követően ismerjük meg az ellenérdekű fél megnyilvánulását:

„Dr Völgyessy Ferenc 40 éves, szegedi születésű, esztergomi lakos, nőtlen orvos, alperes törvényes figyelmeztetés után: eskü alatt vallom a következőket.

1937 év decemberében volt a Rippl 10 éves elhalálozásának emlék kiállítása Budapesten az Ernst Múzeumban. Akkor láttam én a kiállítást. A katalógusból láttam, hogy az özvegy él és a lelkesedésemben írtam neki egy levelet, amelyben valóban arról írtam, hogy nem vagyok gazdag ember, és tudom, hogy Rippl-Rónai nagynevű mester, képeihez nehéz hozzá jutni, és igen szeretném, ha nekem is lenne egy képem. Természetesen nem ajándékba kértem, hanem árat is kértem. A válasz meg is jött, azt hiszem 1938 évben az özvegytől, mindjárt képformájában, ármegjelöléssel, amelyben megírta az özvegy, hogy részletekben is fizethetem a képet. Akkor és addig még nem ismertem az özvegyet. Köszönő levelet írtam és az első részletet küldtem is. Utána minden hónapban jöttek a levélváltások, én küldtem a részleteket. ${ }^{34}$ Levélben a Lazarine néni meg is

32 Az F/4 levél tartalmát nem ismerem. Anella már a per előkészítése során hivatkozott Petrovics sajnálkozására, amire Völgyessy akkor úgy reagált, hogy Petrovics Eleknek (1873-1945) a Szépmüvészeti Múzeum főigazgatójaként többször lett volna rá alkalma, hogy megvásárolja festményt, de soha nem élt a lehetőséggel.

33 A mondat értelmet nyer a későbbiekben idézendő Martyn vallomásból.

34 Számos olyan (a következő évekből származó) levél van a Völgyessy Szomor család birtokában, amelyekben Lazarine nyugtázza a részletek megérkezését. Az idő múltával és a kapcsolat elmélyülésével ismételten találkozunk a „ne aggassza ha kevesebbet tud törleszteni, ahogy jól esik, úgy fizet” tartalmú mondatokkal.

Egy másik levélben olvassuk: „Olyan anyagi helyzetben vagyok, hogy nem tehetek mindent meg amint szeretném nem is [itt két olvashatatlan szó következik G.F.], hogy egy ilyen nagy mủvész özvegye majdnem semmi nélkül maradt, de amit tehetek szívesen adom és el is fogok küldeni egy képet és ahogy tud fizetni úgy törlessze esetleg egy rajzot is fogok küldeni". A levél datálást tartalmazó részét nem ismerem. Közlés betühiven, az eredetinek megfelelően. hívott, hogy nyáron keressem fel. Így 1938 év nyarán Szt. István nap körül pár napot töltöttem Kaposváron. ${ }^{35}$ Ebben az időben vettem három kis dolgot tőle, amit ugyancsak kifizettem. Ugyanekkor kaptam emlékbe egy könyvet, továbbá megkaptam Rippl-Rónai pipáját emlékbe. És apróbb pasztell krétákat, amelyeket ma is őrzök. Ezután is levelezésben maradtunk állandóan. Én 1940 év őszén október 1-e körül Kaposvárra kerültem. Majdnem két évig Kaposváron éltem, min katonaorvos. Gyakori vendég voltam, e közben [láttam GF] az özvegy nagyon nehéz anyagi helyzetét. Úgy, hogy azt lehet mondani minden hónapban adtam neki pénzt, minden anyagi ellenszolgáltatás nélkül. Havi 80 pengős állami kegydíjat kapott. Cipőtalpalásra nem volt pénze, adóra nem volt pénze, a háztartási szükségleteinek beszerzésére sem volt pénze. Ő maga hangsúlyozta, hogy semmi támogatást sem kap. Sőt, ha pénze van, amit titkol előttük, még abból is kérnének. Beszélgetések alakalmával tudtam meg az özvegytől, hogy él egy unokahúga - a felperes - Budapesten és elmondta azt is, hogy mily körülmények játszottak közre a vele való összeköttetés megszakítására.

Akkor ősszel képkereskedők és magánosok is jöttek Kaposvárra, akik képeket vásároltak Lazarine nénitől, például A Szajna éjjel ${ }^{36}$ című elég nagyméretű és nagy értékü képet 400 pengőért vették meg. Ezután egy spanyolországi pireneusi tájat, szintén nagyméretủ képet, 200 pengőért. Láttam ezt az anyagi szorongatott helyzetét, abban az időben én eladtam Szegeden a földrészem és a rám eső részt egy összegben odaadtam Lazarine néninek, ez kétezer pengő volt. És ő ennek fejében, ilyen árban, mint ahogyan az A/4 alatti elismervény feltünteti, eladta az abban feltüntetett képeket. Ezek között a jelen perbeli festményt is, amelyről én nem tudtam, hogy a felperes tulajdona volt. A Lazarine néni a képekröl megjelölte, hogy ez a Róberté, egy másikról is azt mondta, hogy a Róberté, a többi pedig az övé. Felperest akkor én még nem ismertem. Eszem ágában sem volt, hogy a Lazarine néni elad nekem [olyant GF], ami nem az övé. Közbevetöleg elmondom, hogy rengeteg lisztet, cukrot, sót zsírt, borsot és petróleumot, amit ő nem tudott beszerezni én szereztem be részére saját pénzemből és nem fogadtam el érte semmit. Kihangsúlyozni kívánom, hogy még Kaposvárra költözésemet megelőző időben is küldtem neki csomagokat, amelyekröl köszönő leve-

Hálásan köszönöm a Völgyessy Szomor család megtisztelő bizalmát, önzetlen segítségét, köszönöm, hogy a birtokukban lévő leveleket, a gyűjteményre vonatkozó feljegyzéseket megismerhettem, és azok közléshez hozzájárultak.

35 A megerősítő dokumentum Lazarine levele:

„Kedves Juliám és Ferim!

Igen jól esett, hogy itt voltatok, csak kár volt oly rövid időre eljönni, igen hiányoztok jó lenne, ha még együtt lehetnénk. Az idő azóta is egyforma szép, érik a gyümölcs, szőlö, most már lehetne azt is élvezni. Róbert itthon van 3 hétre, segít, ahol lehet örömmel." (Dátum nélküli levelezőlap. Júlia: Völgyessy édesanyja.)

36 A Szajna éjjel, 1898 , olaj vászon, $74 \times 138.5 \mathrm{~cm}$. Ma már a Magyar Nemzeti Galéria tulajdona. MNG. 1998: 264. 
leim vannak ${ }^{37}$. Az Apám-anyám 40 évi házasság után címủ képet ezekért adta nekem Lazarine néni és azokért gyógyszerekért és gondoskodásért, amelyben én őt részesítettem.

Én 1942 nyarán jöttem el Kaposvárról. Szintén mint katonaorvos Szegedre kerültem. A katonaságtól megváltam, jelenleg szolgálaton kívüli orvos őrnagy vagyok a katonaság állományában és esztergomi lakós. A felperest én 1940 karácsony előtt ismertem meg. Én magam készítettem elő felperesnek a Lazarine nénivel való kibékülését, amelyet az ő levelei is tanúsítanak, a levelek a birtokomban vannak. ${ }^{38}$ A perbeni kép lent állt a Lazarine néni szobájában és többször hangsúlyozta, hogy ami itt van, az mind az övé, mert az ura végrendeletileg úgy hagyta vissza, hogy az ingóságok mind az övé, hogy abból tudjon élni. Nem tudtam arról, hogy a kép felperesre lett volna ajándékozva. Az való, hogy ezt a képet 1947 decemberében kiállítottam, a Kultuszminisztérium kérte el tölem. Az összes képeimet és rajzaimat, ami szám szerint 9 darab, és nem 40 , vagy 50 mint ahogy a felperes mondja. ${ }^{39}$ Megemlítem azt, hogy a B/4 alattiban megjelölt képek közül is pl. Tallián Gyula arcképe címú képet ${ }^{40}$ én eladtam a Lazarine néni tudtával és engedélyével, és a pénzt is neki küldettem és juttattam. Ezt én azért tettem, mert láttam a megszorult állapotát. Ez már 1942 vagy 43-ban volt. Az való, hogy egy másik képemmel kapcsolatban is tulajdon igényt érvényesítettek ellenem, de igazoltam, hogy 1945 évben mükereskedőtől vettem, és így rögtön visszakerült az én tulajdonomba.

37 Egyikböl idézek: „A pénzt köszönettel megkaptam, a szalámit is de miért olyan óriásit, nem azért írtam, hogy költekezzen és küldjön ilyen hatalmas szalámit. Volt meglepetésem, hogy lehetett kapni [...] De fogom élvezni a finom rummal és teával a téli esténkint." A levél keltét nem ismerem.

38 Az említett levelekkel nem találkoztam.

39 Lazarine halála idején Völgyessy Ferenc tulajdonában lévő alkotások listája. Zárójelben a gyűjtő által vezetett nyilvántartásban a képek mellett található feljegyzések. A közlés alapjául szolgáló dokumentum magántulajdonban van.

Claudine, olaj, $42 \times 33 \mathrm{~cm}$

Apám, Anyám 40 évi házasság után olaj, 119x160cm. (1940 október)

Alkonyat egy intim szobában, olaj, $65 \times 45 \mathrm{~cm}$. (1940 december, névnapi ajándék)

Ablakterv (Tavasz), tus- akvarell, $14 \times 34 \mathrm{~cm}$

Ádám és Éva, tus-akvarell, $28.5 \times 45.5 \mathrm{~cm}$. (1938 augusztus)

Fejek, tus, $18.5 \times 24 \mathrm{~cm}$

Fenella énekli Carment, tus, $28.5 \times 22.5$ cm.(1942, karácsonyi ajándék)

Két női akt, tus, 29x23 cm. (1940. december 9)

Rajczi szomszéd háza, pasztell, $26 \times 27 \mathrm{~cm}$.

Szundikálás kettesben, pasztell, $38 \times 29 \mathrm{~cm}$

Lazarine, pasztell, 52×42 cm. (1938, névnapi ajándék)

40 Téves kijelentés, a Makfalvay Géza főispánt ábrázoló pasztellek egyikéröl lehet csak szó. A Somogyvármegyei közgyűlés által 1917-ben megrendelt reprezentatív portré az elvárás jellegéből adódóan nehézkesen készült. Rippl-Rónai két előzetes tanulmányt is bemutatott a megrendelőknek, ezek egyikét 1934. április 9-én az Állami Árverési Csarnokban lezajlott hagyatéki árverésen megvásárolták, a másik eladásában müködhetett közre Völgyessy.
Én tudok arról, hogy sok Rippl-Rónai képek vannak Wirth Janka birtokában, aki a Martyn Róbertnek sógornője. ${ }^{41}$ Ez a jelen perbeli kép az enyém, az én tulajdonom, mert szabályosan megvettem. A rokonság egyáltalában nem törődött a képekkel és nem is értettek hozzá. Énnekem kb. száz darab. képem van, amelyeket mind pénzért vettem és nem pedig kicsaltam, ezek kisebb-nagyobb értékűek, de a perbeli képpel azonos kép is van a gyűjteményemben. Nyugodt lelkiismerettel bocsájtottam ezt a képet a kiállításra, mert tudtam, hogy az enyém. Csatolom az A/7 alattit, annak igazolására, hogy Petrovics Elek nem tudta kieszközölni az özvegy kegydíjának elintézését, de én ezt elintéztem, 150 pengőre emelték."

Kölcsönösen kérték tanúk meghallgatását, többeknek felkutatása nem járt eredménnyel. Anella tanúi közül három vallomást idézünk, sorrendben Bernáth Aurél, dr. Martyn Róbert és dr. Rónai Györgyét

Bernáth Aurél:

\section{„Nyilatkozat}

A Pestvidéki Törvényszék 1949. március 25-re Dobossy Elekné felperesnek dr. Völgyessy Ferenc alperes ellen indított perében tanúkénti kihallgatásra voltam idézve, melyen a becsatolt orvosi bizonyítvány szerint megjelenni nem tudok s így tanúvallomásom helyett az alábbi nyilatkozatot teszem.

Dr. Völgyessy Ferencet még az 1930-as évekből ismerem. Megismerkedésem vele úgy kezdődött, hogy egy festő barátomra hivatkozva feljött a lakásomra s arra kért, hogy ajándékozzam neki egyik festményemet. Hivatkozott arra, hogy több festőtársam is segíti őt abban, hogy egy kis gyűjteménye keletkezhessen.

Völgyessy dr. úr kérését én indokolatlannak találtam s azt megtagadtam. Egyéb kapcsolatom vele nem volt. Nevét itt-ott müvészkörökben hallani lehetett s így arról is értesültem, hogy mint katona-orvos Kaposvárra került.

Személyéről és gyűjtési szenvedélyéről egy későbbi kaposvári tartózkodásomkor bővebben volt alkalmam hallani. Családi kapcsolataim folytán 1943-ban Kaposváron tartózkodtam, ahol régi ismerősömet özvegy Rippl-Rónai Józsefnét is felkerestem. Az özvegygyel való beszélgetésemkor ő említést tett nekem arról, hogy ismeri Völgyessy doktort, vele jó barátságban van, kijár hozzá, dacára a nagy távolságnak s kijárt hozzá még a legkeményebb tél idején is. Az özvegy nem győzte Völgyessy doktor ragaszkodását dicsérni, elmesélte hogy a doktor zongorázásával szórakoztat-

41 Ezt az állítását Völgyessy még a per megkezdése előtt kifejtette Anellának, aki egy Martyn Róberthez írott levelében utalt is erre az állításra (és lehetőségre). Ezzel együtt Anella ugyanebben a levelében azt kérte, hogy a megindítandó perben (a korábbi örökösödési ügyben kialakult nézeteltérésük ellenére) Martyn Róbert tegyen vallomást mellette. Ismét beleütközünk tehát a hagyatékban maradt Rippl-Rónai művek rejtélyébe. A levél a szerző birtokában van. 
ja. A beszélgetésünk folyamán érdeklődtem Rónainak egy pár híresebb festménye után, melyek azelőtt az özvegy birtokában voltak. „Több képet a doktornak ajándékoztam" volt az özvegy válasza.

Már akkor ott a helyszínen az volt a benyomásom, az esetről, hogy az idős hölgy /akkoriban 80 esztendős lehetett/ egy késői rajongással viseltetik Völgyessy doktor iránt. Másképp sehogy sem tudtam magamnak megmagyarázni ezeket a nagy értékü ajándékokat.

Ha jól emlékszem még ugyanebben az évben hallottam azonban egy másik esetet is, amely a pesti művészeti körökben széltében-hosszában feltűnést keltett. Nem kisebbről volt szó, mint a kaposvári Múzeumban lévő Bonnard francia festő Rippl-Rónait ábrázoló arcképének Völgyessy doktor úr által való megszerzéséről. ${ }^{42}$ Nem akartam vallomásomat pusztán emlékezetemre bízni, így vettem magamnak a fáradtságot, hogy a kaposvári Múzeum jelenlegi igazgatójához forduljak s megkértem, hogy erre a kép megszerzésre vonatkozó muzeális irattári adatokat másolja ki számomra. Ez meg is történt. Vallomásom pótlásául tehát én ezeket az eredeti iratokat a felperes kezébe adom azzal, hogy ő azokat mutassa be.

A Bonnard - Rippl-Rónai képcsere nézetem szerint abban nélkülözi a formális eljárás szabályait, hogy sem a kérelmezés alkalmából, sem az átvételnél özvegy Rippl-Rónai Józsefné aláírása nem szerepel. Dr. Völgyessy úrnak 1942. II. 16-án kelt levelének azt a passzusát, hogy «szegény jó Nagyságos Asszony érdekét mindig szem előtt tartom és érte mindent megteszek» nézetem szerint erőtlenné teszi az a tény, hogy tudomásom szerint Völgyessy doktor ezt a képet rögtön a megszerzés után Budapesten értékesítette, ahogy akkoriban értesültem 6.000 pengőért. Ezen adatnak hitelessége után annakidején nem jártam.

42 Az esettel a kaposvári sajtó is foglalkozott:

Uj Somogy 1942. 57. 2 p

"Mi értékesebb: Rippl-Rónai utolsó festménye, vagy Bonnard: Rippl-Rónai portréja?

A Somogyvármegyei Múzeum igazgatójához, Gönczi Ferenc ny. tanfelügyelöhöz levél érkezett Rippl-Rónai Józsefnek, Somogy nagyhírű festőjének özvegyétől. Az özvegy a levélben kéri a Somogyvármegyei Múzeumot, hogy a múzeum adja át neki Bonnard francia festőművész által férjéről készült tanulmányfejet. Nem ellenszolgáltatás nélkül kéri azonban erre a múzeumot. Ugyanis az özvegy a Somogyvármegyei Múzeumnak nagyhírú férje utolsó képét egy pasztell-festésủ arcképét ajánlotta fel. Az özvegy kérését azzal indokolja, hogy nem maradt fenn kép uráró és ily módon szeretne egy olyan festményhez jutni, amely urát ábrázolja.

A Somogyvármegyei Múzeum vezetősége részéről a múzeum igazgatója, Gönczi Ferenc a Stephaich Pál alispánnal folytatott megbeszélés után felterjesztést intézett a Nemzeti Múzeumhoz, a kérdéses két képet is felküldve. A múzeum vezetősége arra kért választ a Nemzeti Múzeumtól, hogy belemenjen-e a cserébe? Az esetleges csere által nem károsodna-e meg a múzeum? A Rippl-Rónai festőművészről francia művész által készített tanulmányfej egy kartonon készült, meglehetősen megviselt állapotban lévő pasztell, míg az özvegy által felajánlott női arckép, amely a híres somogyi művész utolsó alkotása, szintén kartonon lévő pasztell, jellegzetes Rippl-Rónai kép, lehelet finomságú színezéssel festve. A Nemzeti Múzeum dönti majd el, melyik festmény értékesebb, Rippl-Rónai utolsó képe-e, vagy a francia festőművésznek Rippl-Rónairól készült tanulmányfeje?"

A fennmaradt Völgyessy dokumentumok között az előzőekkel kapcsolatos feljegyzést a hagyaték tulajdonosai nem találtak.
Budapest, 1949. III. 24

Bernáth Aurél főiskolai tanár"43

\section{Dr. Martyn Róbert.vallomása (részlet)}

„A családban is, bennem is az a benyomás keletkezett az alperes magatartásával kapcsolatban, hogy az alperes meglehetősen kihasználta a művész özvegyét és sok képet elhordott jóformán ajándékba. Alperestől kapott a művész özvegye a képekért élelmiszert is, pénzt is, de az alperes részéröl történt eme juttatások aránytalanul csekélyek voltak a képek értékéhez viszonyítva. Jellemző esetként megemlítem, hogy a művész özvegye az Apám, Anyám címủ festményt nekem ígérte halála utánra, ennek ellenére alperes azt elvitte, miként az özvegy nekem említette, csak azért kapta meg ideiglenesen az alperes azt a képet, hogy lakását díszítse vele. A kép azonban többé nem került vissza. A felperesi képviselő által felmutatott, Kolozsvárott 1942. december hó 20-án keltezett és általam a felpereshez intézett levél tőlem származik és annak tartalma a valóságnak mindenben megfelel; a most felmutatott levél második oldalán írottaknak megfelelően ezen levelet megelőző időben írtam az alperesnek, aki válaszlevelében azt írta nekem, hogy visszaad mindent, de Lazarine néni, a mủvész özvegye, nem fogadja vissza a képeket. Emlékezetem szerint azt nem írta ebben a válaszlevélben az alperes, hogy a képeket megvette, hanem olyan értelemben írt, hogy azokat ő ajándékba kapta a művész özvegyétől."

\section{Dr Rónay Gusztáv 55 éves törvényszéki tanácselnök (részlet)}

„[...] Alperes később, a háború folyamán mint orvos főhadnagy Kaposvárra került és kezdetben a kaposvári 533. sz. hadikórház Apponyi utcai részlegénél volt beosztva; ugyanitt volt a lakása egy primitíven, szokásos katonai egyszerüséggel berendezve, amit onnan tudok, mert nálam is, - bizonyára mint a festőművész unokaöccsénél - látogatást tett és én ezt a látogatást az említett kórházi lakásán viszonoztam. A látogatásom alkalmával meglepetéssel észleltem, hogy az alperes szobájában egy nagyobb méretü perzsaszőnyeg van, amely azelőtt nagybátyám Róma villájában volt; úgyszintén meglepetéssel láttam az egyszerüen berendezett kórházi lakószobában nagybátyámnak az ApámAnyám című nagyméretű muzeális értékű festményét, melyen az alakok életnagyságban voltak ábrázolva, és ugyancsak láttam ott több kisebb képet is, melyek

43 Szelesi Zoltán művészettörténész Völgyessy Ferenc gyűjteményét bemutató tanulmányában sajnálattal állapítja meg, hogy Bernáth Aurél egyetlen alkotásával sincs képviselve abban. Kézenfekvő de felszínes - lenne elfogadnunk, hogy az idézett vallomásában lelhetünk rá a jelenség magyarázatára. A feltételezést cáfolata, hogy Völgyessy, a képeiröl vezetett nyilvántartásának tanúsága szerint Bernáth egy olyan jelentős alkotását szerezte meg (Tanárnő, pasztell, 70x50), amelyet maga az alkotó, Fruchternek írott levelében egyenesen „bübáj”-nak minősített.

Szelesi, Z. 1984: 302

Rum, A. 2007: 115-116 
szintén nagybátyámnak Rippl-Rónai Józsefnek művei. Alperes úgy látszik észrevette meglepetésemet, mert azt a megjegyzést tette, hogy ezeket a festményeket és szőnyeget nagybátyám özvegyétől kapta, azért, hogy az egyébként egyszerű és rideg lakószobája lakályosabb legyen [...] Nagybátyám özvegye befolyásolható volt, különösen a vele szemben tanúsított kedvezésekkel, kedveskedésekkel kapcsolatosan."

A per csak 1949-ben zárult le. A dr. Katona Gábor esztergomi ügyvéd által ellenjegyzett datálás nélküli (!) iraton csak annyi szerepel: „A képet visszakaptam Dobossyné"

A Fővárosi Képtárban 1952 október-novemberben megrendezett emlékkiállításon a Claudine már a Fővárosi Képtár tulajdonaként került a látogatók elé. ${ }^{44}$

Bár Völgyessy neve többször szerepel a magyar mügyűjtés történetének bemutatása során, személyes életrajzi vonatkozások ismertetésével nem találkozunk. ${ }^{45}$ Völgyessy Ferenc (1908. augusztus $14-1992$. április 24) az Szegedi Orvostudományi Egyetem elvégzését követően bőrgyógyász szakképesítést szerez. Szegedröl 1941-42 -ben katonaorvosként Kaposvárra, majd a frontra kerül. Különös módon, személyes tárgyként ott is magánál tartja Rippl-Rónai Ádám és Éva című grafikáját. A háború végén Unterbibergben amerikai fogságba esik, ahol a kép megsemmisül. ${ }^{46} \mathrm{Az}$ ekkor már jelentősnek mondható gyűjteménye banki letétként átvészeli a háborút. Megválva a katonaságtól Esztergomban intézetvezető főorvos. Az első volt, aki a háborút követően magángyűjtőként vállalta a nyilvánosságot (1953), annak ellenére, hogy őt is érintette korlátozott mértékü államosítás. ${ }^{47}$ Egyre több időt tölt Budapesten, ahol a legjelentősebb gyűjtőkkel kialakult kapcsolata révén élénk társasági életet él. A nagymüveltségü orvos igényes gyűjteménye a magyar képzőművészet vezető mestereinek fömúveit tartalmazza. Összetétele folyamatosan változik, mindig az éppen aktuális egyéni gyűjtői koncepciója alapján. Szinte egyedülállóan jellemző rá, hogy megválik jelentős művektől, majd nem sokkal később ismét visszaszerzi azokat. Gyakran hangoztatott alapelve volt, hogy a tőle kikerülő mütárgyak soha ne hagyhassák el az országot.
Gyűjteményét többször is bemutatta: 1965 -ös szegedi kiállításán 146 alkotást láthattak a látogatók. Közöttük a hét Rippl-Rónai mellett Szinnyei, Gulácsy, Csontváry, Ferenczy, Mednyánszky, Szőnyi, Egry, Aba-Novák és mások műveit is. ${ }^{48}$ Egy-egy hozzá közelálló gyűjtővel való szorosabb kapcsolatának nyomai a kollekciók alakulásában kölcsönösen felismerhetők, ilyen például Fruchter Lajos, vagy az esztergomi Dévényi Iván, akinek hatására Czóbel Béla és Miháltz Pál is képviselethez jutott gyűjteményében.

Nem csak gyűjtött, előszeretettel és elmélyülten foglalkozott a hozzá közel álló művészek munkásságával. Erről Kaposvári tartózkodása idején is tanúbizonyságot tett:

„Tartalmas, komoly előadás hangzott el tegnap, kedden délután 6 órakor a Szabadegyetemen az egyházközségi székházban, ahol Völgyessy Ferenc dr. honvéd főorvos tartotta előadását városunk világhírű festőjéről, Rppl-Rónai Józsefröl. Völgyessy Ferenc dr. ismeretlen volt eddig a Szabadegyetem előadói asztalánál. Bemutatkozó előadása nyomán azonban a közönség kitűnő alapossággal képzett előadót ismert meg benne, aki úgy látszik nem csak az orvosi tudományban, hanem a képzőművészetben, annak ismeretében is megállja a helyét. Völgyessy dr. egyébként közeli rokona a nagyhírü kaposvári festőnek, akinek müvészetét ismertette előadása keretében s mint ilyen, leghivatottabb magyarázója Rippl-Rónai különös egyéniséggel telített müvészetének. Az előadáson megjelent özv. Rippl-Rónai Józsefné, a nagyhírű festő Kaposváron élő özvegye is, akit a Szabadegyetem közönsége az előadás végén melegen ünnepelt. A megjelentek soraiban ott láttuk városunk művészetbarát közönségét szép számban. [...] Rippl-Rónai József rövid életleírásával kezdte előadását Völgyessy Ferenc dr. majd a továbbiakban vetített képekkel illusztrált mondanivalóját Rippl-Rónai József

44 Fővárosi Képtár. Rippl-Rónai Emlékkiállítása Budapest, 1952 október-november III. terem Kat. 19

Elgondolkodtató, hogy alig három évvel visszaszerzését követően Anella megválni kényszerült a családi emléktől. Eladóként Dobossy Elek szerepel. A festményeladások alkalmával mindig csak a férj nevével találkozhatunk a szerződéseken

45 Ébli, G 2006: 195-197. Ébli egy mondatban említi, hogy „a föorvos még ismerte a művész özvegyét, így nem merült fel a hamisítás veszélye."

46 A Völgyessy Szomor család szóbeli közlése.

47 Kitünő vívó és lovas volt. A család közlése szerint esélye volt rá hogy dijlovaglásban szerepelhessen a Helsiki-ben megrendezett olimpián, ami lovának elvétele miatt (vagy annak okán) hiúsult meg.

48 Szelesi, Z. 1984

A gyűjtemény Rippl-Rónai képei (a grafikai alkotások nélkül) 1965-ben:

Apám, Anyám 40 évi házasságuk után, olaj

Lazarine, pasztell

Szundikálás kettesben, pasztell (MNG, 1998:73)

Jön a vihar Schlesingeréknél már esik, pasztell (Reprodukálva: Magyar Művészet, III. 1927, 128 kép)

Rajczi szomszéd háza, pasztell

Lajos öcsém, olaj (MNG. tulajdona, Rippl-Rónai Lajos képmása címmel. 70x100. Reprodukálva: Új magyar Képtár, 2. kiadás, 446 kép. Budapest, 1976)

Újhold, olaj

A későbbiekben került a gyűjteménybe: Az óceán Banyuls-surMernél, 1899, olaj, karton, 50x75.

A BÁV 67. képaukción, 1985 szeptember Kat. 140 Vihar a tengeren címen árverezett „védett” (?) mű jelenlegi tulajdonosa The Salgo Trust for Education, USA. 
művészetét, küzdelmes életének jelentősebb epizódjaival, állomásaival hozta kapcsolatba és így előadása nem fárasztó életrajz ismertetés, hanem élvezetes, figyelmet lekötő volt."49

A másik helyi lap híradása az esemény előtti napon jelent meg:

„Rippl-Rónai Józsefről rendeznek vetítettképes elöadást. Vetített képekben ismerhetjük meg a somogyi festő legszebb képeit

[...] Az előadó asztalhoz ezúttal Völgyessy Ferenc honvéd főorvos ül, aki annál a kapcsolatnál fogva, amely őt a művész családjához füzi legilletékesebb magyarázója a Rippl-Rónai képeknek. A kiváló müértő honvéd föorvos hosszas tanulmányainak eredményét adja át a múélvező hallgatóságnak" 50

Nem ez az egyetlen eset, amellyel Völgyessy múvészetelméleti érdeklődését illusztrálhatjuk. Aba Novák Vilmossal való barátságának nyomán született meg 1938-ban a Délmagyarországban közölt írása: Aba Novák Vilmos beszél az öncélú és alkalmazott művészetről, a mai müvész problémáiról. ${ }^{51}$

A Lazarinnal való, többféleképpen értelmezhető kapcsolata megítélhetőségéhez nagy jelentőségü fennmaradt levelezésük tanulmányozása, amelyből egy a mozgalmas társasági életből kiszakadt, minden vonatkozásban magányossá váló özvegy és az ambiciózus, lelkesedő fiatal gyűjtő kapcsolatának alakulását követhetjük nyomon. Lazarine - akinek nem volt saját gyermeke, nevelt lányának „elvesztését” követően Martyn Róbertre és Völgyessy Ferencre egyaránt úgy tekintett, mint újra meglelt gyermekeire. Leveleiben folytonosan központi helyen szerepel a rossz egészségügyi állapotával kapcsolatos panasz áradat. Keserüen írja Völgyessynek:

„Két orvos fiam van, de egyik sincs velem, egyik sem tud rajtam segíteni." 52

A levelezés azt bizonyítja, hogy a szoros kapcsolat kettejük között nem Kaposváron alakult ki, bár nem tagadható, hogy ekkor teljesedett ki igazán; az már évekkel korábbra datálható. Azt nem tudjuk, hogy a

49 Somogyi Ujság XXIII. 59, 1-2 1941. március 12 szerda

Az előadáson elhangzottakról - az idézetteken túlmenően - terjedelmes és részletes ismertetést olvashatunk, amelyből kitünik, hogy mai szemmel is helytállóak és értékesek voltak Völgyessy megállapításai a festő pályaképéről, korszakolásáról, művész teljesítményéröl.

A rokoni kapcsolatról elterjedt szóbeszédet Rippl-Rónai Józsefné személyes jelenléte hitelesíthette. A következő lapszámokban nem jelent meg helyesbítés, vagy cáfolat. Az ünneplés Lazarinban is növelhette a „hála” hőfokát.

Délmagyarországban (1938. március 20)

50 Uj Somogy 23.1941. 56, 2

51 Délmagyarország, 1938. március 20

52 Dr. Martyn Kolozsváron, dr. Völgyessy Szegeden élt. A levél az örökösök birtokában van, keltezését nem ismerem. Érdekességként: Völgyessy gyűjtötte a bélyegeket és többségüket akkora kivágással távolította el, hogy a postai bélyegzés ideje nem megállapítható. Ez azért is sajnálatos, mert Lazarine ritkán datálta leveleit. harmincas évei elején járó katonaorvos Kaposvárra kerülése vezénylés, vagy sikeres egyéni kezdeményezés következménye volt-e. Az előzőekben bemutatott perben Anella becsatolt egy levelet, amely Völgyessy „hízelgését” volt hivatott bizonyítani:

„Alig várom a pillanatot, hogy édes Lazarine nénit karjaimban tarthassam. Nagyon sokat gondolok édes Lazarine nénimre és nagyon sok szeretettel ölelem és csókolom szerető fia: Feri." ${ }^{3}$

Lehetőségünk nyílott megismerni azokat a leveleket is, amelyeket (már az Anella által becsatoltnál korábban keletkezve) Lazarine küldött Völgyessynek. Közülük kettőt betühíven idézhetek, amelyek valamiféle kettejük között kialakult „éteri kapcsolat” meglétére utalnak. Nincs adatom arra, melyikük használta (kezdeményezte?) elsőként ezt a különleges viszonyt minősítő szópárt, de láthatóan mindketten elfogadták (megélték?) a sajátos „anya - fiú” szerepet.

\section{II/12}

Drága Ferencem édes Fiam leveledet megkaptam minek nagyon megörültem és értem belöle hogy 16-án akarsz csak jönni mert édes anyáddal együtt születésnapot akartok ülni azt itt is meglehet tartani és én már nagyon szeretnélek látni úgy téged mint Édes anyádat, így ne halasszuk a jövetelt hanem minél előbb jöjj szeretettel várlak Édesanyáddal ${ }^{54}$ együtt. Sok szeretettel ölel mindig szerető anyád

Édes anyádat sokszor üdvözlöm szeretettel!" (3. ábra)

\section{„1943. II/6}

Drága fiam. Kedves lapodat megkaptam amit nagy örömmel olvastam de drága fiam hogy én utazzak, arról szó sem lehet mert nagyon beteg vagyok és ha nem volnék ilyen beteg a mostani viszonyok közt akkor sem tudnék elmenni hanem nagyon megköszönlek hogy ha lehet úgy jöjj fel te mert nagyon szeretnék veled élőszóval több mindent megbeszélni. Ha csak lehet jöjj minél előbb. Sok szeretettel csókolom Édes Anyádat is. Téged sok szeretettel csókol

\section{Anyád \\ Még egyszer kérlek okvetlen jöjj}

Sok csók"

Az utolsó általam megismert levél arról tanúskodik, hogy törlesztő részlet (vagy támogatás?) a bekövetkezett nagy társadalmi megrázkódtatások közepette is megérkezett.

53 Részlet a már bemutatott perbeni, Dobossy Elekné által csatolt F/ 2 számú bizonyítékból. Keltének időpontja nem ismert.

54 Völgyessy édesanyjával együtt 1938-ban már meglátogatta Lazerine-t a Róma hegyen. Ld.: $35 \mathrm{lj}$. 


\section{$94211 / 2 e-5$}

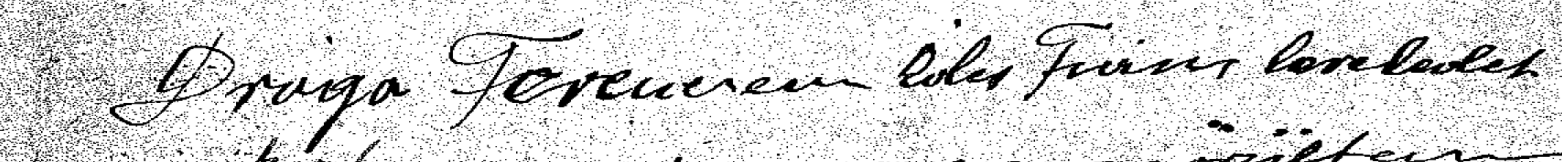

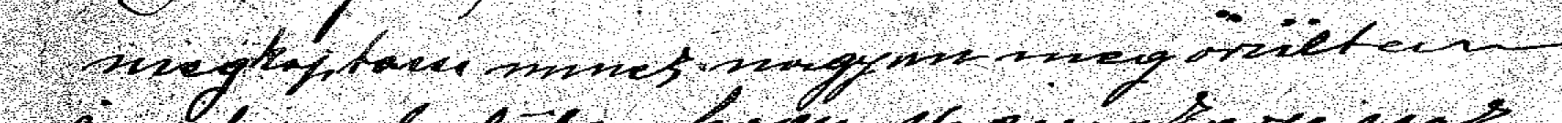

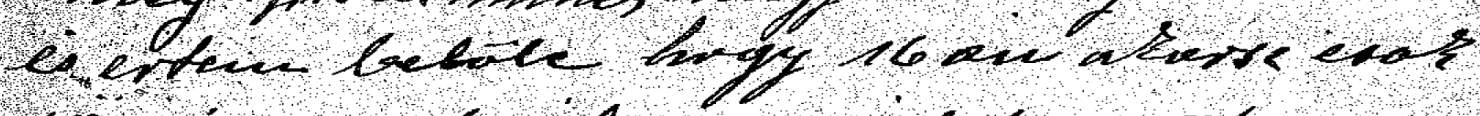

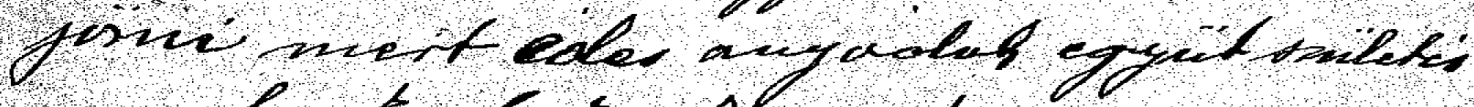

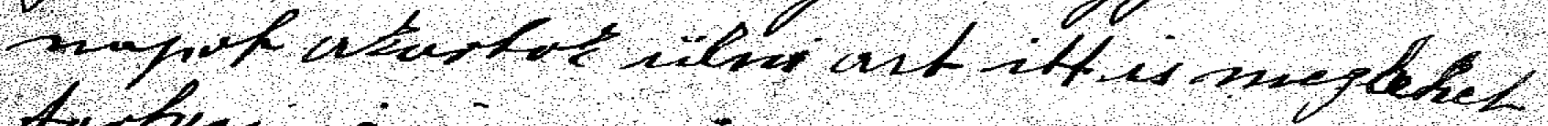

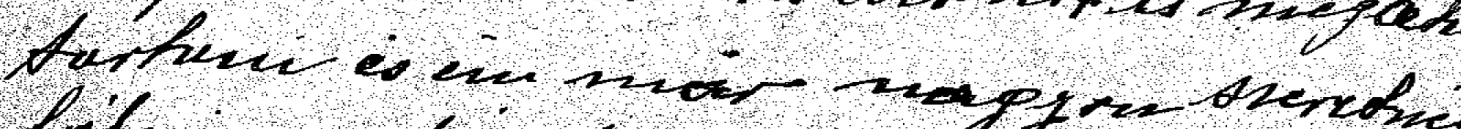

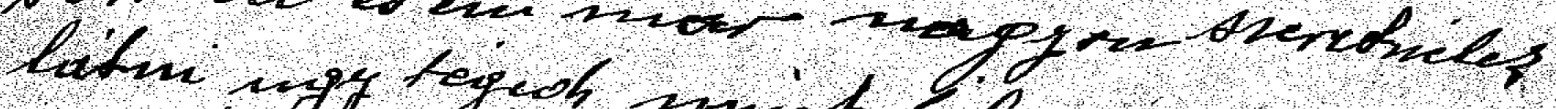

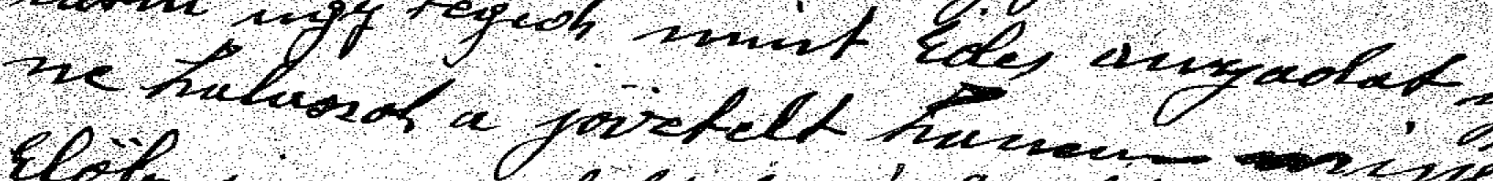

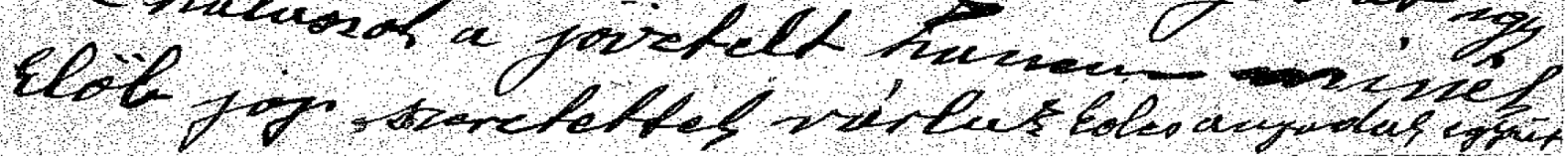

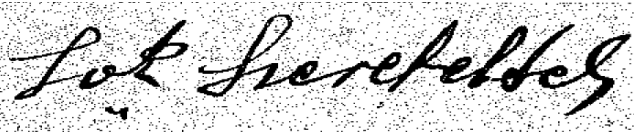

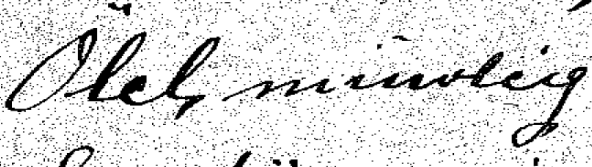

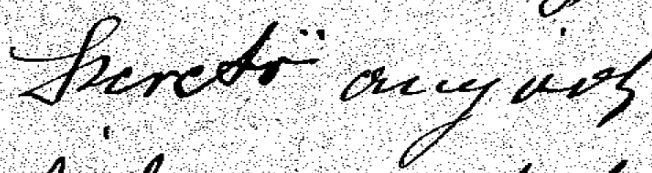
Cof

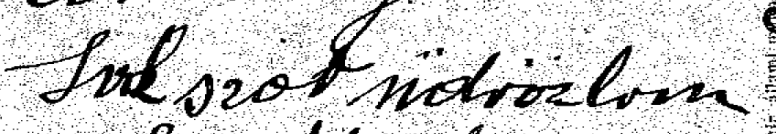

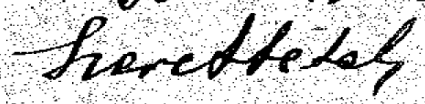

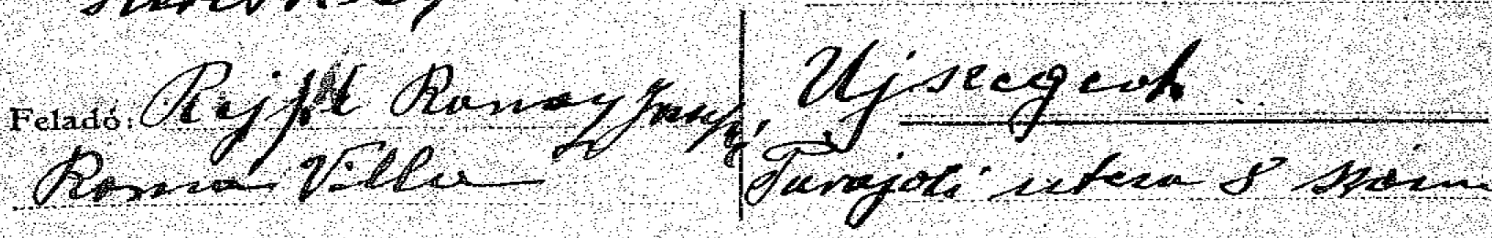


Nagyon köszönöm kedves lapjait és a húszezer pengőt, nagyon örültem néki.

Most már jól vagyok, de sajnos nagy baj történt velem. Éjjel két fegyveres katona kirabolt és megtámadott revolverrel két helyen beverték a fejemet, elvesztettem az eszméletemet és agyrázkódást szenvedtem. Most már aránylag..." 55

55 A levél folytatását nem ismerem. Megállapítható, hogy a hagyatékban fennmaradt (megismerhető) levelek közül azok kerültek elsősorban látóterembe, amelyek Völgyessy perbeni vallomásának igazságtartalmát voltak hivatottak bizonyítani. Erre utal, hogy ezek a részletek meglehetősen hangsúlyos módon - feltehetően a perrel egyidejüleg, az arra való felkészülés során erőteljes aláhúzással - kiemelésre kerültek. Találkoztam olyan levelekkel is, amelyek - az íráskép alapján nyilvánvalóan - diktálás útján születtek, csak az aláírás származik Lazarine-től.

\section{Irodalom}

Az Est, 3. évfolyam, 1933. 96. 5

Az Est, 3. évfolyam, 1933. 97. 5.

ÁlLAMI ÁRVERÉSI CSARNOK 1934: Rippl-Rónai József művészi hagyatéka. Katalógus. Budapest, 1934

ERNST Múzeum 1915: Rippl-Rónai József háborús festményeinek és rajzainak kiállitása. Katalógus. Budapest, 1915

ERNST MúZEUM 1928: Rippl-Rónai József emlékkiállítása. Katalógus. Budapest, 1928

ERNST MúzEUM 1937: A Rippl-Rónai József halálának 10 évfordulójára rendezett kiállítás. Katalógus. Budapest, 1937

ÉBLI, G. 2005: Budapest műgyűjtők városa. Beszélő, 2005 márciusáprilis, 10 évf. 3 szám

ÉBLI, G. 2006: Magyar műgyűjtemények. Budapest, 2006

F. CsANAK, D. (szerk) 1992: Fülep Lajos levelezése II 1920 -1930 Budapest 1992

FőVÁROSI KÉPTÁR 1952: Rippl-Rónai József Emlékkiállítása Katalógus. Budapest, 1952

HoRVÁTH, J. 1992: A Rippl-Rónai hagyaték. Somogyi Múzeumok Közleményei IX. Kaposvár, 1992.
Összegezésként megállapítható, hogy az elhangzott vádak ellenére - miszerint az alkotások méltatlan körülmények között kerültek ki a Róma villából -, viszszaszerzésükre a lehetséges örökösök körében nem történt kísérlet, vagy igény bejelentés. A Claudine 1949-ben megvalósult "hazatérésével” a történetet lezárhatjuk, azt követően ismét felhőtlen az ég a Róma villa felett.
HoRvÁTH, J. 1995: Rippl-Rónai Emlékkönyv Paris Anella visszaemlékezéseivel Rippl-Rónairól. Kaposvár, 1995

KAPOSVÁR 1957: Rippl-Rónai József halálának 30. évfordulójára rendezett Emlékkiállítás. Katalógus. Kaposvár, 1957

Magyar Nemzetı Galéria 1998: Rippl-Rónai József Gyűjteményes Kiállítása. Katalógus Budapest, 1998

Nemzeti Szalon 1947: Rippl-Rónai József Emlékkiállítása. Katalógus. Budapest, 1947

PeWny, D. 1940: Rippl-Rónai (1861-1927). Budapest, 1940

Rum ATTILA (szerk.): Küldj egy kis optimizmust Bernáth Aurél levelei Fruchter Lajoshoz. Budapest, 2007

SOMOGYI UJSÁG XXIII. 1941, 59

SOMOGYI VILÁGOSSÁG II. 1947, 153

SzELESI, Z. 1984: Műgyűjtés Szegeden. Móra Ferenc Múzeum Évkönyve 1984/85. Szeged, 1985

UJ SOMOGY 23.1941. 56, 2

UJ SOMOgY 24.1942. 57, 2 


\section{Storm clouds above the "Róma Villa" The afterlife of the Rippl-Rónai legacy}

\section{FERENC GÁSPÁR}

The final will and testament of the wife of József RipplRónai induced conflicts amongst the relatives claiming parts of the legacy. Strangely, the intellectual legacy of the painter - his works of art - were not included on the legacy list, but despite of this fact was no excuse for any altercations between them. In our work, we try to follow the traces of the wandering of his creations.

Significant artworks ended up at a young collector's, who became owner of more main works (chef - d'oeuvre) of the painter during the last years of the widow - as a result of the strong spiritual bond formed between them. The stepdaugther of the painter, Anella Páris started a lawsuit to get one of these paintings back, because she had already received that artwork from the artist himself years ago, so no one else had a right to claim it for him- or herself. The witness confessions at the trial seemed to confirm that more paintings might have ended up under inappropriate and unworthy circumstances at this collector's, not just the artwork known by the name 'Claudine'. We demonstrate the proceeding based on original court transcripts.

We use letters from private collections to demonstrate the relationship between the widow and Ferenc Völgyessy (1908-1992), who later on became quite a significant collector of art. We also present the story of the collection that includes the artwork of the greatest Hungarian painters (Szinnyei, Ferenczy, Gulácsy, Csontváry, etc.); nonetheless, we think that the accusations mentioned above were more than excessive. 